J. Perinat. Med.

13 (1985) 67

\section{Ultrasound investigation of the fetal cerebral ventricles}

\author{
V.D'Addario, A. Kurjak* \\ 1st Department of Obstetrics and Gynecology, University of Bari, Italy \\ * Ultrasonics Institute Dr. J. Kajfeš Hospital, Zagreb, Yugoslavia
}

\section{Introduction}

One of the earliest clinical applications of ultrasound in obstetrics was the measurement of the biparietal diameter of the fetal head to determine gestational age. Until recently little attention was paid to the use of ultrasound in the evaluation of fetal intracranial anatomy.

Recent improvements in ultrasound technology, particularly the introduction of new high-resolution real-time instrumentation favor the detection of fine structural intracranial details such as the fetal cerebral ventricles (FCV).

The ultrasonic analysis of the normal ventricular anatomy by physicians involved in obstetric sonography gives the possibility of choosing the exact scanning plane for cephalometry and making an accurate and early diagnosis of pathological conditions such as hydrocephaly. We report here our experience in the ultrasonic evaluation of 280 normal and 8 hydrocephalic fetuses.

\section{Material and methods}

Ultrasound examinations were performed using an ALOKA 250 real-time phased array system with $3.5 \mathrm{MHz}$ probe. Real-time images were photographed using a POLAROID camera. Two hundred eighty obstetric patients with normal pregnancies were studied from the 14 th to the 41 st completed week of pregnancy. Eight patients with antenatally

\section{Curriculum vitae}

VINCENZO D'ADDARIO was born in Bari, Italy, 1950. He studied Medicine at the University at Bari and graduated in 1975 . He spezialized in obstetrics and gynecology in 1979 and he is currently working at the 1st Department of Obstetrics and Gynecology, University of Bari. He was trained in ultrasonography in obstetrics and gynecology in the Ultrasonic Center of Zagreb, Yugoslavia. Ultrasonography is his main field of research interest.

detected hydrocephalic fetuses were also included in the study.

\section{Results}

\subsection{Ultrasonic features of the fetal cerebral ventricles}

The best plane of scanning to detect most details of the cerebral ventricles is the axial one, obtained at different parallel levels, beginning at the vertex of the fetal head. This is best done when the fetal head is in an occipitotransverse position (Fig. 1 A). In this case, when a $3.5 \mathrm{MHz}$ transducer is used, the ventricle distal to the transducer is often visualized better than the proximal one, because it 


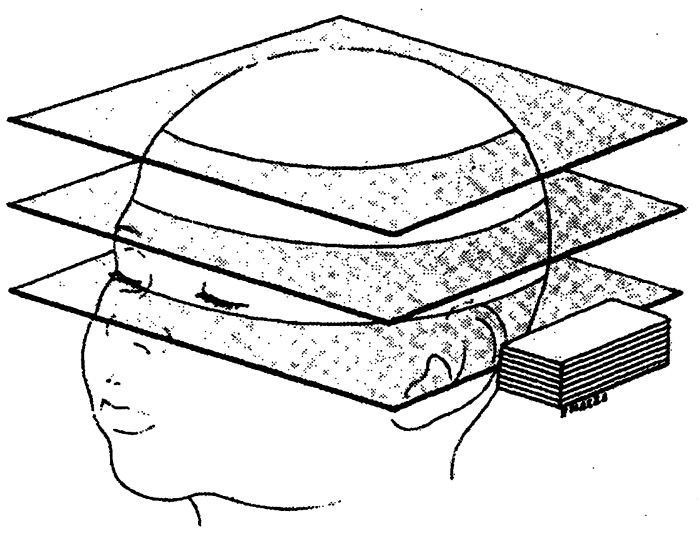

A

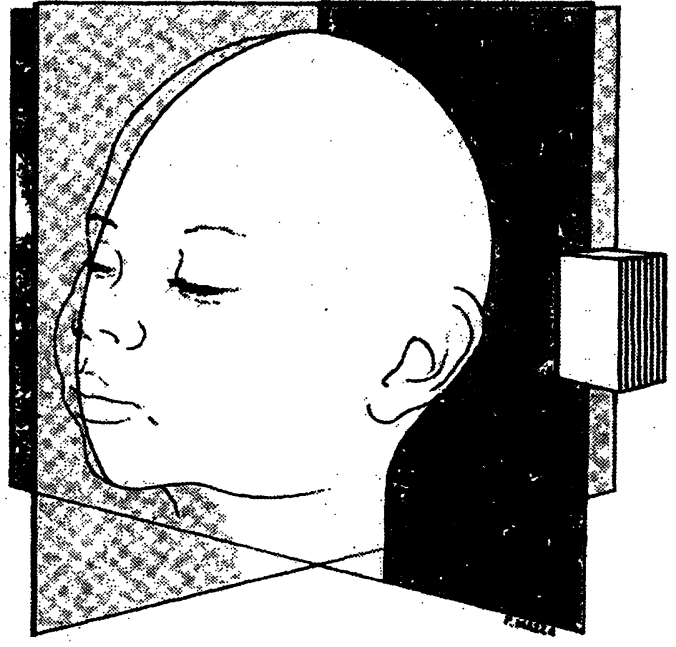

B

Fig. 1. Diagrammatic sketches of the planes of scanning which can be made on the fetal head $(A=$ axial scans; $B=$ coronal and sagittal scans).

falls in the optimal focal field of the ultrasonic beam. The ventricles are somewhat difficult to visualize at term if the fetal head is in a vertex position and deep in the pelvis, or if the head is in an antero-posterior projection.

Coronal and sagittal planes can also be obtained but not easily (Fig. 1B); they are easier to obtain when the fetus is in breech presentation. The fetal head can be visualized using ultrasound starting from the 9th gestational week but clear visualization of the cerebral ventricles is possible only after the 13th week. At this early stage of pregnancy the lateral ventricles are quite large compared to the size of the cerebral hemispheres [9]. They occupy more than 50 percent of the hemispheres and are not yet differentiated into frontal horns, bodies, atria, occipital and temporal horns. The lateral walls are easily recognised and appear as two thin lines which are parallel to the midline echo (Fig. 2). The midline echo is rather thick because, at this stage, it consists of three very close parallel lines; the external ones represent the medial walls of the lateral ventricles, while the middle one represents the falx and the fornix.

The ventricular cavities are not completely anechoic but contain two small echogenic structures corresponding to the choroid plexi. At this early gestational age, the choroid plexi are very large and occupy a great part of the ventricular cavities (Fig. $3 \mathrm{a}$ ). Their strong echogencity is probably due to the rich glycogen content, typical of the early stages of pregnancy $[3,13]$.

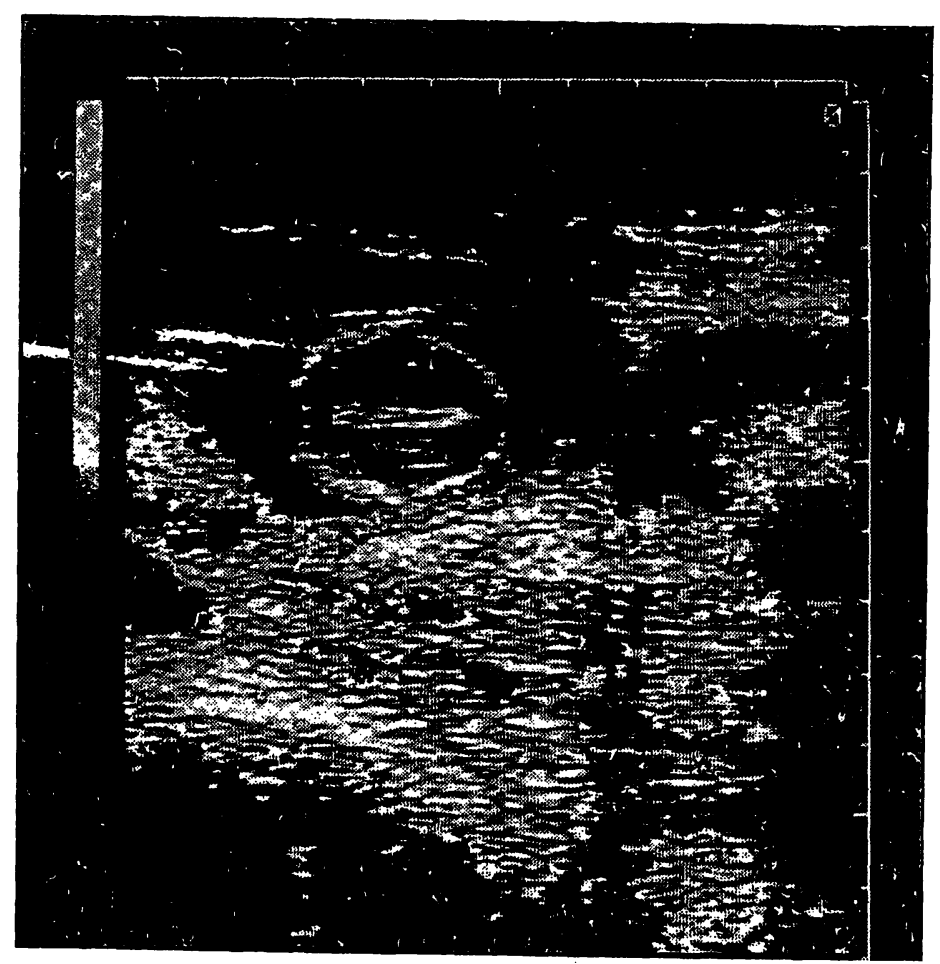

Fig. 2. Ultrasonic appearance of the lateral ventricles at 14 weeks. Note the three-line finding of the midline echo. 

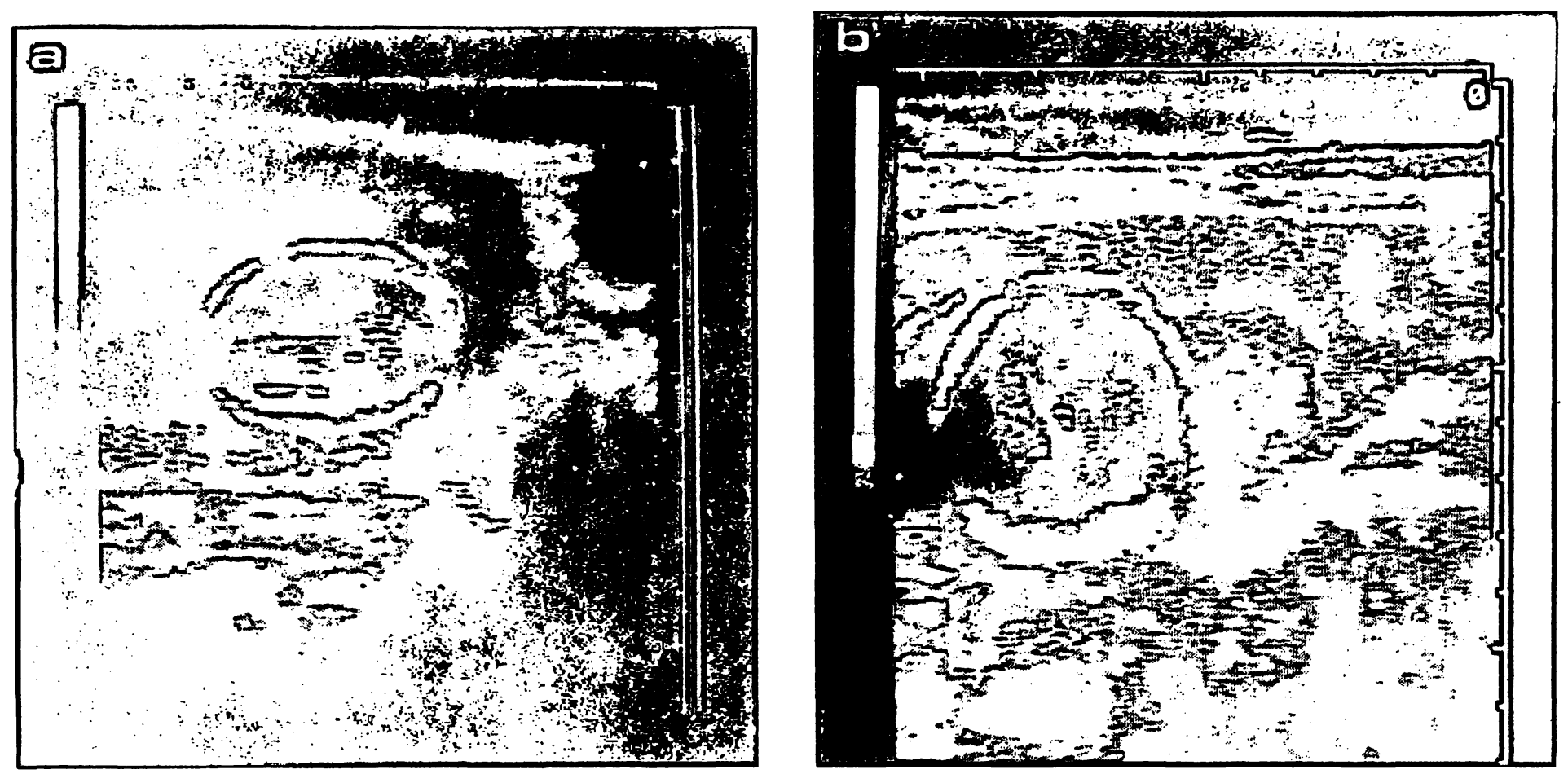

Fig. 3. Ultrasonic appearance of the choroid plexi at 17 weeks. $a=$ the walls of the lateral ventricles are also identified $\mathrm{b}=$ the walls of the lateral ventricles cannot be identified because the fetal head is on antero-posterior projection.

Sometimes, especially in the antero-posterior projection, the choroid plexi are the only intracranial structures which can be detected during this period, because the lateral walls of the lateral ventricles cannot be visualized. They appear as two pear-shaped echogenic structures inside the cerebral hemispheres which, on the contrary, are anechoic (Fig. 3b).

The impossibility of visualizing these lateral walls in the antero-posterior projection, when a linear array is used, is due to the fact that the ultrasonic beam is parallel to them and accordingly there is no reflective surface.

From the 18 th to 19 th gestational week the ultrasonic appearance of the lateral ventricles is different, because of the fetal ventricular differentiation. When serial axial scans are performed starting from the fetal vertex, two thin lines parallel to the midline echo are detected. These lines correspond to the lateral walls of the bodies of the lateral ventricles. These linear echoes are occasionally seen to diverge anteriorly and posteriorly to form the frontal and occipital horns respectively (Fig. 4). An axial scan made $1-2 \mathrm{~cm}$ more caudally shows a typical image consisting of four short and thin echogenic lines parallel to the midline echo. Two of them lie near the frontal pole and two near the occipital pole of the fetal head. The anterior lines, which are farther from the midline echo than the posterior ones are correspond to the lateral walls of the frontal horns of the lateral ventricles; the posterior ones correspond to the medial walls of the posterior horns of the same ventricles. It is important to point out that the term "posterior horn" is not quite correct, because the true posterior horn takes its ultimate shape after the 25 th week. The proper term should be "posterior part of the body of the lateral ventricle" corresponding to the atrium. We shall continue to use the term "posterior horn" for simplicity's sake and in order to conform to the common terminology. The lateral wall of the posterior horn cannot always be visualized as clearly as the medial one, probably because it runs postero-laterally and therefore does not act as an interface perpendicular to the ultrasound beam. With good high-resolution instrumentation along with proper regulation of the gain-setting and a little tilt of the probe, it is possible to visualize the lateral wall too; in this way, both the anterior and the posterior horns of the lateral ventricle can be globally identified (Fig. 5). 

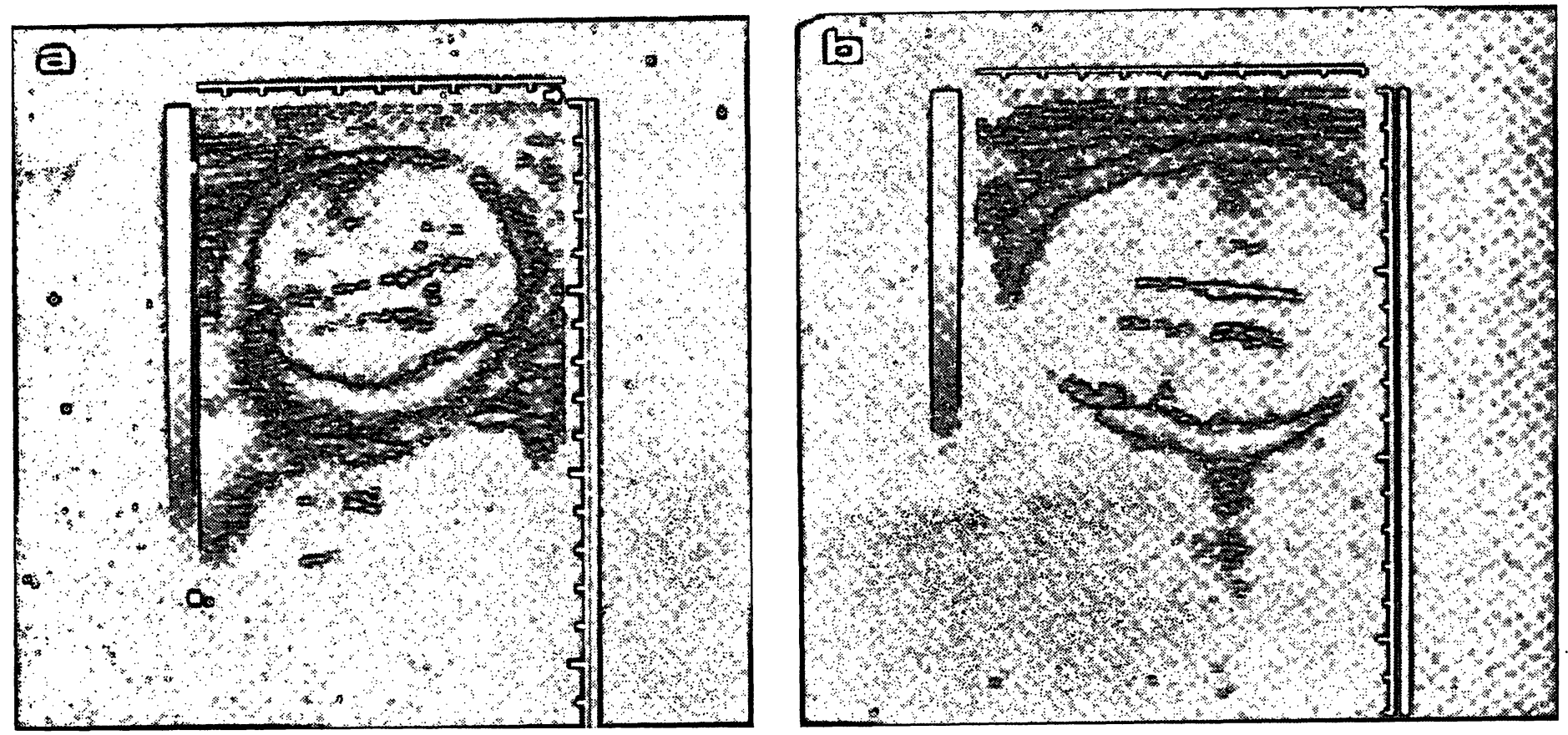

Fig. 4. Lateral walls of the bodies of the lateral ventricles $(a=27$ weeks; $b=30$ weeks)

At this point one can see the posterior horn diverge slightly from the midline echo; if one imagines that the medial wall of the anterior horn and the lateral wall of the posterior one are eliminated from the picture shown in Fig. 5, one will obtain the superposition of this picture with the above-mentioned four-line image.

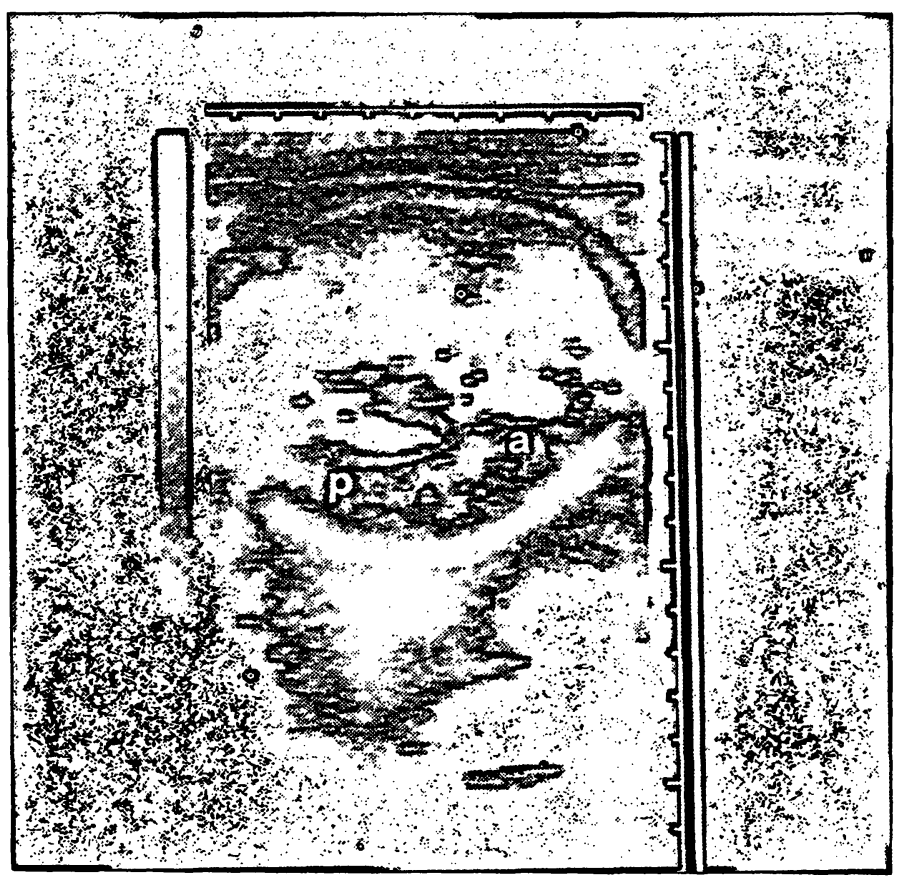

Fig. 5. Ultrasonic appearance of the lateral ventricle at 31 weeks. ( $a=$ anterior horn; $b=$ posterior horn).
As the lateral ventricles undergo the afore-mentioned modification in shape, the choroid plexi, which in early pregnancy filled a great part of the ventricular cavities, now become smaller and can be identified prominently inside the posterior horn [3] (Fig. 5).

An axial scan performed immediately below the plane where the frontal horns are observed shows a small anechoic area interrupting the midline echo. This area lies near the frontal pole at one-third of the fronto-occipital diameter and is delimited by two short linear echoes (Fig. 6). Its width is 4-5 $\mathrm{mm}$ at term. For a long time some authors had considered this structure as representing the walls of the 3rd ventricle $[1,6]$. However, it is more likely to represent the cavum septi pellucidi [14, 17], although other authors [10] ascribe it to the trunk of the corpus callosum at a point where its walls are perpendicular to the ultrasonic beam.

The true 3rd ventricle is slightly posterior and caudal to the septum pellucidum. Since it is a very narrow cavity not wider than $2-3 \mathrm{~mm}$, it is somewhat difficult to visualize it before the 28 th week $[14,17]$. The optimal scanning plane is always the axial one with a slight posterior tilt of $15^{\circ}-20^{\circ}$. In this way the 3 rd ventricle appears as two thin linear echoes which are parallel and very close, and located between the two anechoic thalami (Fig. 7). 


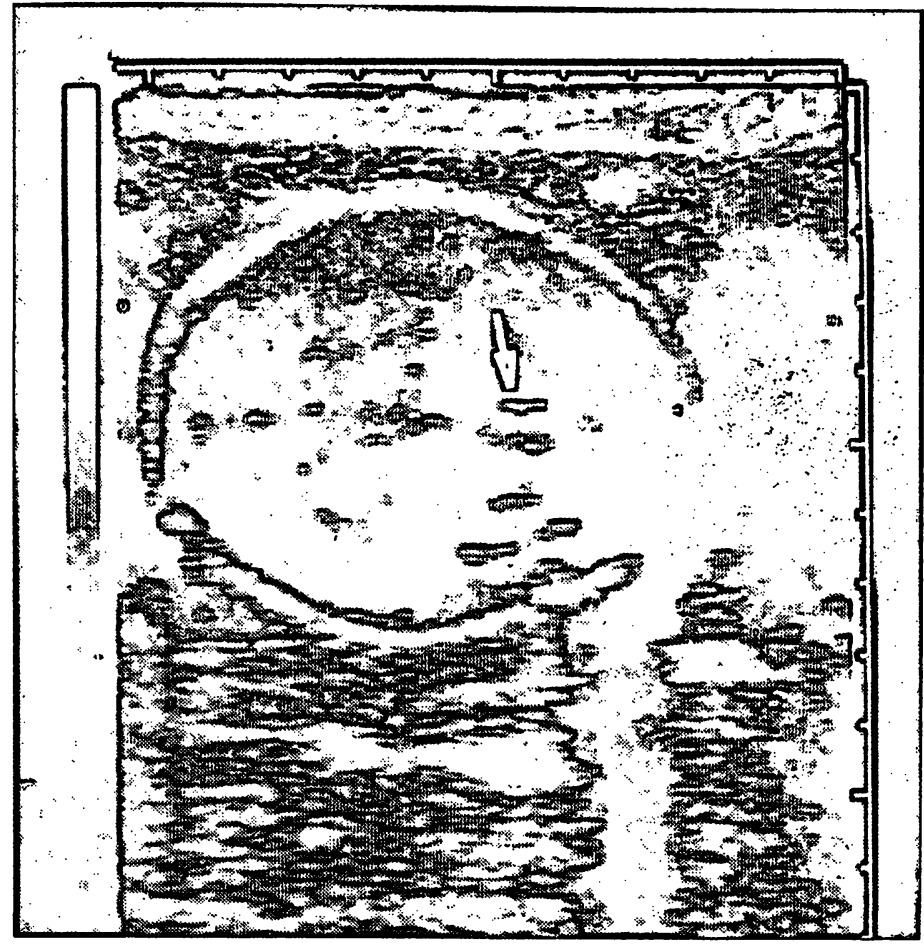

Fig. 6. Axial scan passing through the cavum septi pellucidi (arrow).

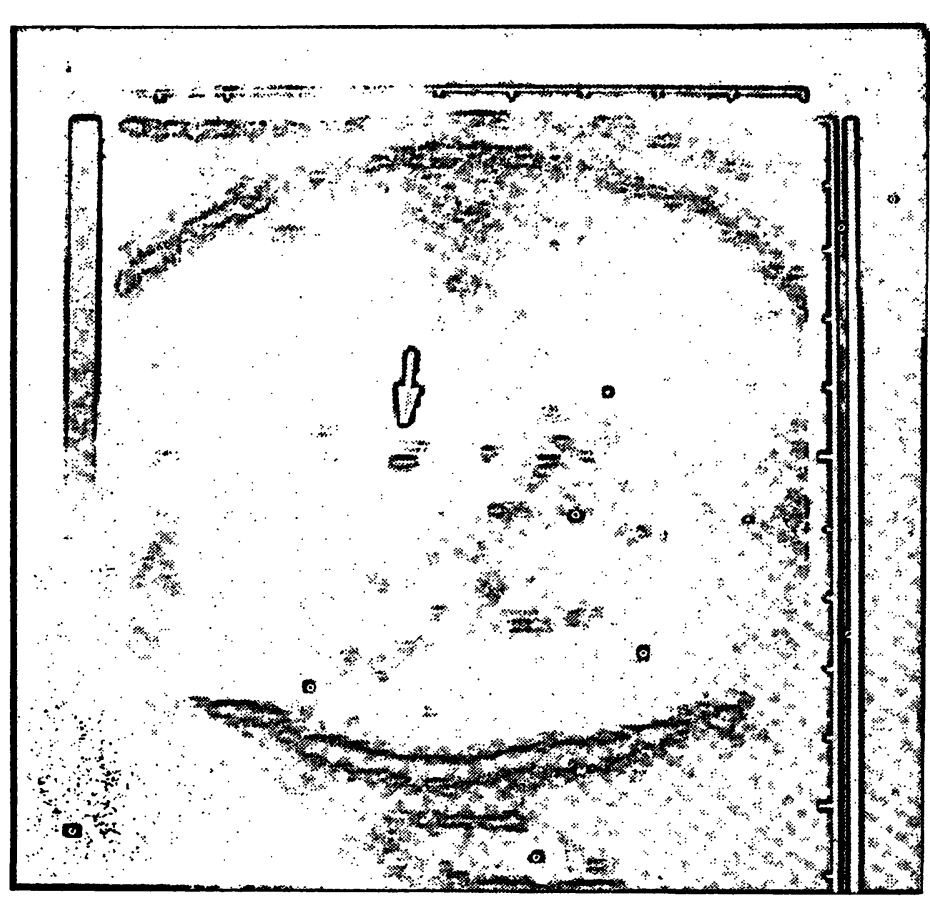

Fig. 7. The third ventricle (arrow) appears as a thin fissure which is located posteriorly and caudally to the septum pellucidum.
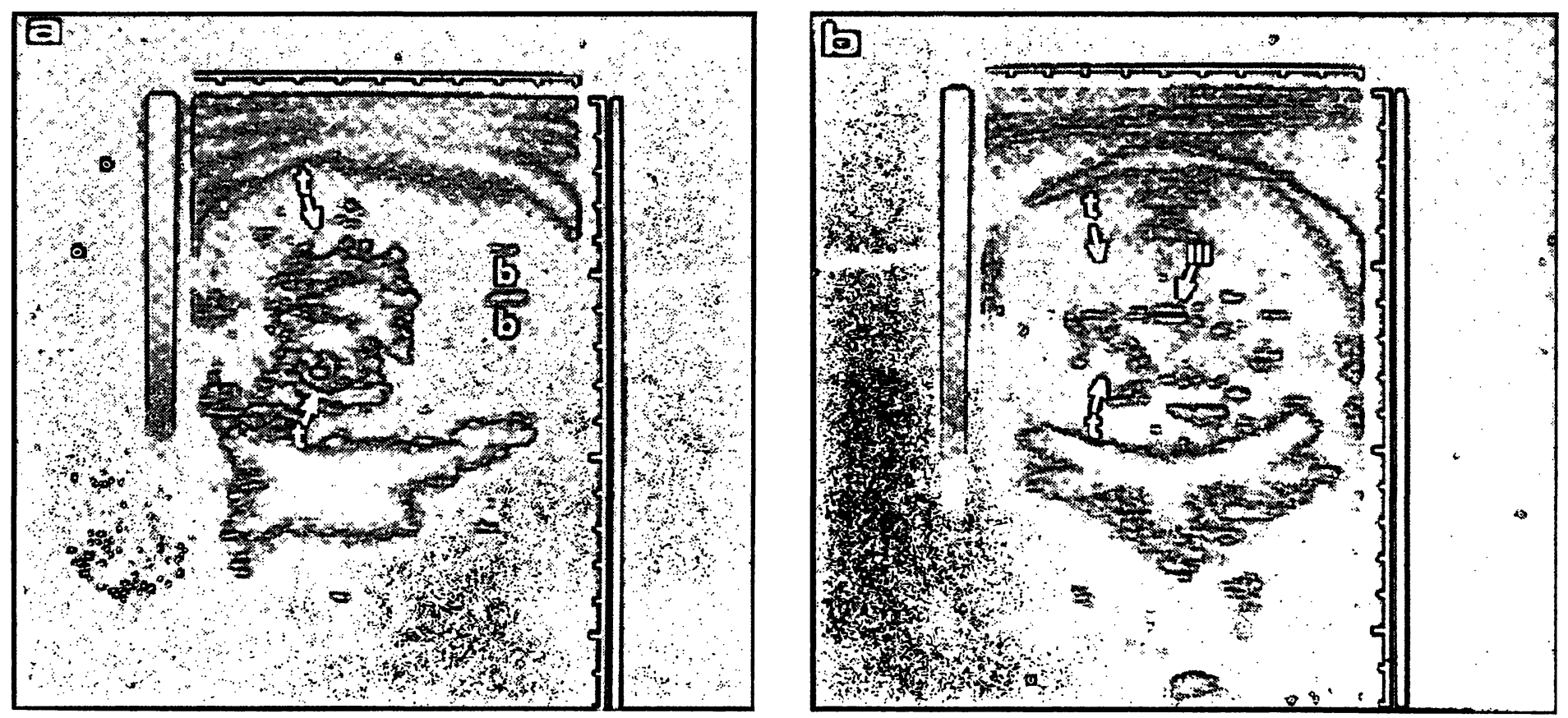

Fig. 8. Temporal horns of the lateral ventricles; they appear as two small roundish anechoic areas laterally to the brainstem and hippocampus. The scanning plane is axial but deeply inclined downward and backward (in Fig. a the inclination is greater than in Fig. $b)$. $(t=$ temporal horns; $b=$ bodies of the lateral ventricles; III $=3 \mathrm{rd}$ ventricle). 

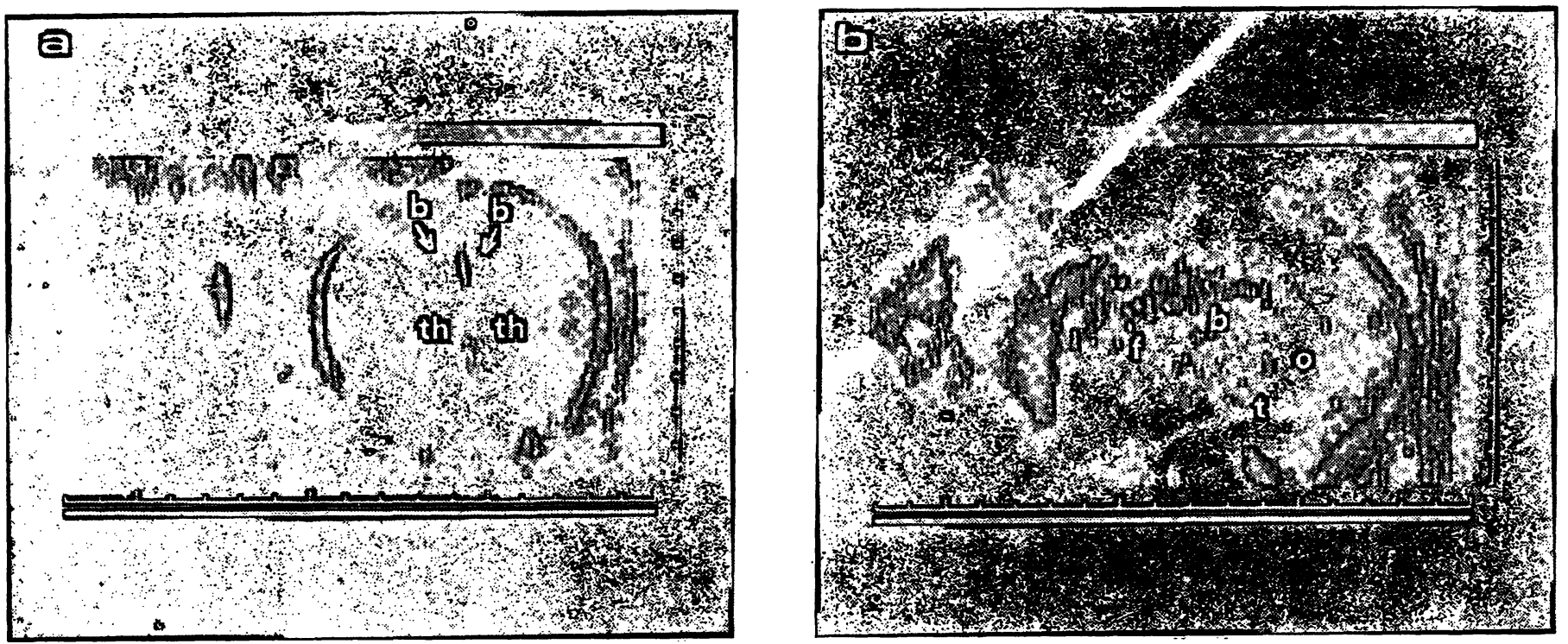

Fig. 9. Coronal (a) and sagittal (b) section of the fetal head $(b=$ bodies; $f=$ frontal horn; $o=$ occipital horn; $t=$ temporal horn; th $=$ thalami).

So far we have described the ultrasonic features of the fetal ventricles obtained with axial and parallel scans, which can be performed very easily on the fetal head in utero.

Nevertheless, in certain particular conditions such as the breech presentation, it is sometimes possible to make scans on different planes, allowing one to complete the ultrasonic anatomy of the fetal cerebral ventricles.

By means of axial and craniocaudally inclined scans, the inferior or temporal horns of the lateral ventricles are identified as two small roundish cystic areas lateral to the brain stem and hippocampus (Fig. 8a); these areas include some echoes produced by the choroid plexi. The $3 \mathrm{rd}$ ventricle can also be visualized on the same plane (Fig. $8 \mathrm{~b}$ ).

Coronal scans allow one to identify the bodies of the lateral ventricles as two small anechoic areas lying laterally to the midline echo and above the thalami (Fig. 9a). Sagittal scans can be obtained with great difficulty, but reveal the lateral ventricle as a whole (frontal horn, body, occipital and temporal horns with the choroid plexus inside) (Fig. 9b).

\subsection{Ventricular measurements}

Once the fetal cerebral ventricles have been ultrasonically identified, they can be measured to assess ventricular growth. By means of ventricular measurements, therefore, a prenatal diagnosis of hydrocephaly can be made. To obtain an early and definitive diagnosis of hydrocephaly, the most useful measurement is the lateral ventricle width/ hemispheric width ratio $[2,4,11]$. In fact, the lateral ventricles are very large during the first half of pregnancy and occupy a great part of the cerebral hemispheres: as pregnancy proceeds, their volume is gradually reduced compared to the cerebral tissue volume; this is why the ventricle/hemisphere ratio has a greater diagnostic value than the measurement of the lateral ventricle width.

Since the lateral ventricle has a complicated shape, it is necessary to select a landmark, at which the measurement should always be made. The lateral wall of the frontal horn is undoubtedly the most easily identifiable part of the lateral ventricle; for this reason the ventricular measurement is to be taken at this point or in the most anterior part of the lateral wall of the ventricular body. The distance between this lateral wall of the lateral ventricle and the midline echo is then measured (Fig. 10). This distance is slightly greater than the true frontal horn width, because the medial wall of the frontal horn lies just laterally to the midline echo. This medial wall can be identified only in early pregnancy. For this reason, the midline echo which is always easily identifiable, is perfer- 

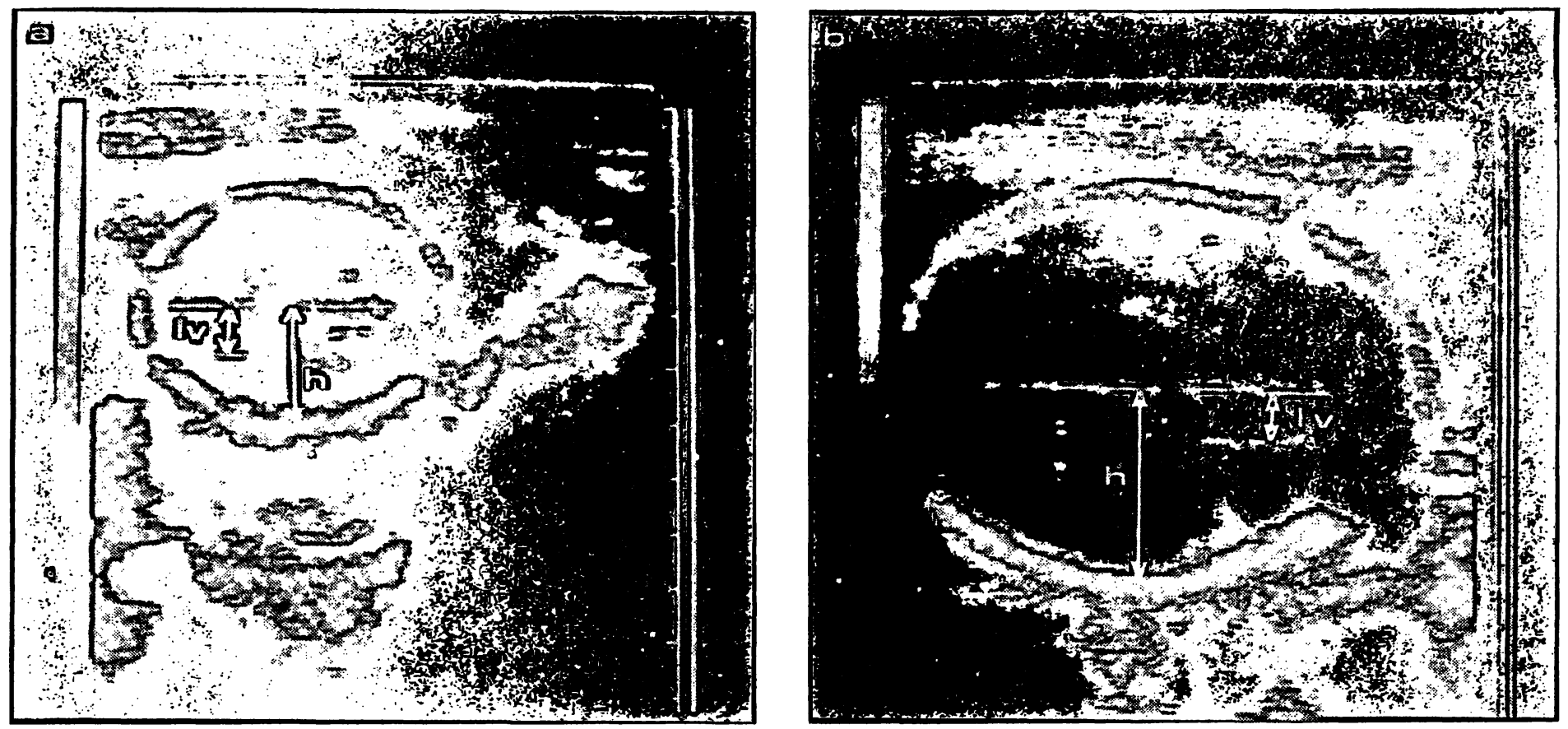

Fig. 10. Method of measurement of the lateral ventricle width (lv)/hemispheric width $(\mathrm{h})$ ratio. $(\mathrm{a}=17$ weeks; $\mathrm{b}=27$ weeks).

red as a landmark instead of the medial wall of the frontal horn.

The greatest hemispheric width is also measured at the same level as the ventricular width. These

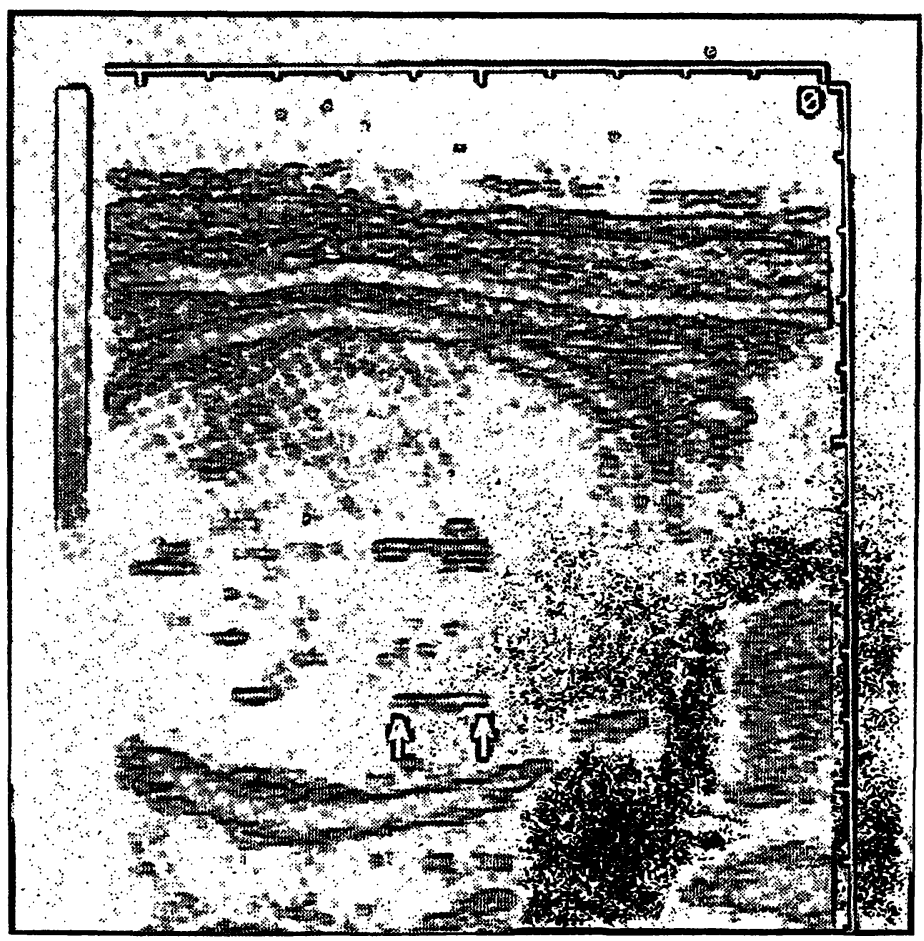

Fig. 11. Ultrasonic appearance of the sylvian fissure (arrow). This linear echo should not be confused with the lateral wall of the lateral ventricle. measurements should be taken from the inner edge of the midline echo to the inner edge of the ventricular wall and to the inner edge of the distal parietal bone respectively (Fig. 10).

A potential source of error in determining the lateral ventricle width/hemispheric width ratio (LVW/HW) lies in mistaking the sylvian fissure for the lateral wall of the ventricular body; such a mistake could be the cause of erroneous diagnosis of hydrocephaly. The sylvian fissure can be distinguished easily from the ventricular wall because it lies more laterally at a slightly lower level (Fig. 11). Furthermore, real-time examination will demonstrate pulsations of the middle cerebral artery within this area, identifying it as the sylvian fissure.

The LVW/HW ratio changes during pregnancy according to the changes of the ventricular size compared with that of the hemisphere.

Tab. I shows the values of the ventricular width, the hemispheric width and the LVW/HW ratio ( $\pm 2 \mathrm{SD}$ ) as measured in 280 normal pregnancies from the 14 th to the 41 st week of gestation.

A statistical analysis was made with a third degree polynomial using the $X^{2}$ minimization method. The third degree polynomial relationship between 
Tab. I. Values of ventricular width, hemispheric width and LVW/HW ratio ( $\pm 2 \mathrm{SD}$ ) in 280 normal pregnancies from 14 to 41 weeks.

\begin{tabular}{lcccccc}
\hline & \multicolumn{2}{l}{ LVW } & & HW & \multicolumn{2}{c}{ LVW/HW } \\
\cline { 2 - 7 } Weeks & M & 2SD & M & 2SD & M & 2SD \\
\hline 14 & 7.4 & 1.6 & 12.3 & 1.9 & 0.61 & 0.09 \\
15 & 8.2 & 3.0 & 14.1 & 4.6 & 0.58 & 0.15 \\
16 & 8.0 & 1.0 & 15.2 & 1.8 & 0.52 & 0.06 \\
17 & 8.7 & 1.4 & 17.4 & 4.0 & 0.50 & 0.10 \\
18 & 8.5 & 1.4 & 18.5 & 2.8 & 0.46 & 0.12 \\
19 & 8.9 & 2.0 & 21.2 & 2.2 & 0.41 & 0.11 \\
20 & 8.1 & 0.6 & 21.9 & 3.0 & 0.37 & 0.06 \\
21 & 8.4 & 1.0 & 23.4 & 2.8 & 0.36 & 0.08 \\
22 & 8.3 & 1.0 & 24.5 & 3.6 & 0.34 & 0.03 \\
23 & 8.5 & 1.0 & 26.3 & 3.0 & 0.33 & 0.05 \\
24 & 8.7 & 3.0 & 27.5 & 3.4 & 0.31 & 0.10 \\
25 & 9.0 & 2.0 & 28.8 & 4.0 & 0.31 & 0.06 \\
26 & 9.0 & 1.4 & 30.1 & 4.0 & 0.30 & 0.06 \\
27 & 9.3 & 2.0 & 32.3 & 3.8 & 0.29 & 0.06 \\
28 & 10.0 & 2.2 & 33.5 & 4.0 & 0.29 & 0.07 \\
29 & 10.0 & 1.8 & 35.6 & 4.6 & 0.28 & 0.04 \\
30 & 10.5 & 1.4 & 36.0 & 2.6 & 0.29 & 0.04 \\
31 & 11.0 & 1.2 & 37.0 & 3.6 & 0.29 & 0.03 \\
32 & 10.7 & 3.0 & 39.0 & 3.0 & 0.28 & 0.07 \\
33 & 11.4 & 1.6 & 38.6 & 2.1 & 0.30 & 0.02 \\
34 & 11.1 & 1.6 & 40.6 & 6.4 & 0.27 & 0.03 \\
35 & 11.9 & 1.6 & 42.4 & 3.8 & 0.28 & 0.05 \\
36 & 11.9 & 1.6 & 42.7 & 5.0 & 0.28 & 0.04 \\
37 & 11.5 & 2.8 & 41.9 & 4.4 & 0.28 & 0.06 \\
38 & 12.2 & 1.3 & 42.8 & 9.9 & 0.29 & 0.06 \\
39 & 12.8 & 3.0 & 44.8 & 5.4 & 0.29 & 0.04 \\
40 & 12.4 & 2.8 & 44.4 & 4.0 & 0.28 & 0.06 \\
41 & 11.7 & 1.0 & 42.3 & 7.0 & 0.28 & 0.05 \\
\hline
\end{tabular}

LVW/HW (y) and gestational age ( $\mathrm{x}$ ) (14-41 weeks) was:

$y=0.6727-0.0602(x-13)$

$$
+0.00308(x-13)^{2}-0.000052(x-13)^{3}
$$

The curve obtained which relates the LVW/HW ratio to the weeks of pregnancy is shown in Fig. 12. The $\mathrm{LVW} / \mathrm{HW}$ ratio is 0.61 (range $0.52-0.77$ ) at the 14th week and decreases, rapidly at first and then gradually, to 0.29 (range $0.24-0.34$ ) at about the 27 th week. This value then remains unchanged until term, apart from another slight decrease during the last two weeks. The data obtained are in good agreement with those reported by other authors $[6,10,11,12]$. Some small differences may be due to different methods of measurement. The LVW/HW ratio, therefore, decreases as the

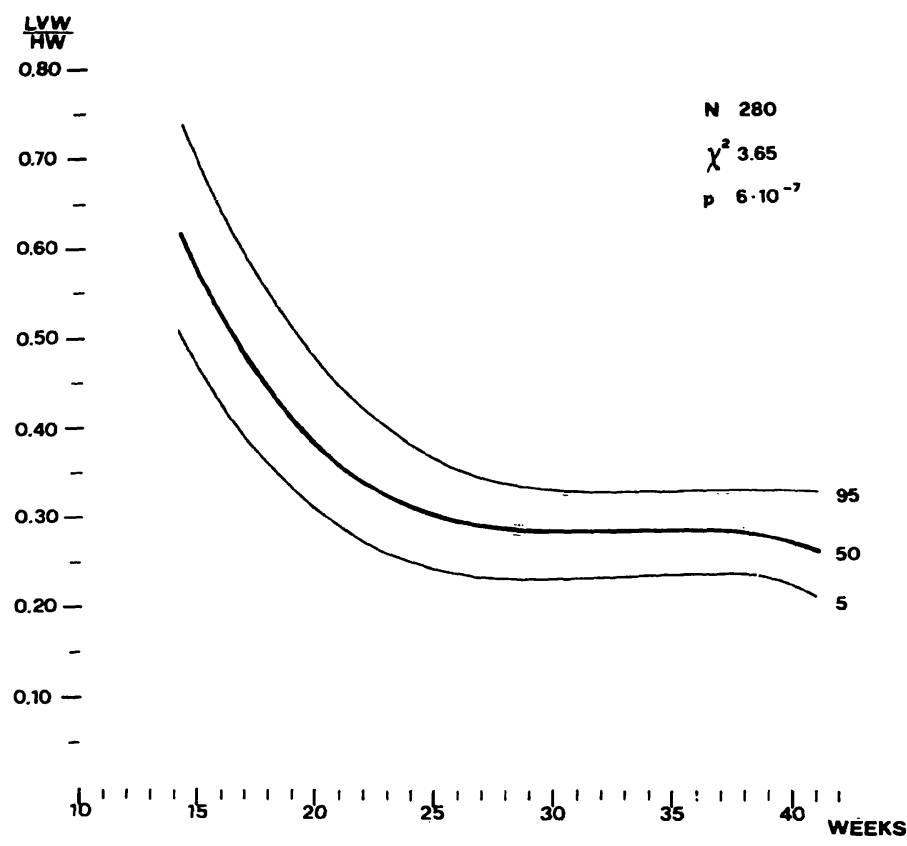

Fig. 12. Normal values of the LVW/HW ratio versus gestational age.

fetus grows, reflecting the developmental anatomical changes.

Thanks to this simple measurement technique, it is possible to diagnose hydrocephaly much earlier than by means of the identification of an abnormal BPD growth or a discrepancy between head and abdomen circumferences [7, 15].

A higher value of the $\mathrm{LVW} / \mathrm{HW}$ ratio is the first evidence of a pathological dilatation of the fetal ventricles while BPD is still contained within the normal range. Fig. 13 shows the values of the LVW/HW ratio we found in eight cases of hydrocephaly. Although the earliest reported cases of prenatal ultrasound detection of hydrocephaly have been at $17-18$ weeks $[16,18]$, one must be very careful when making the diagnosis prior to 20 weeks because the lateral ventricles are usually disproportionately large at this time and the LVW/ HW ratio is high. Moreover, the normal range is rather wide at this age. For this reason it is useful to repeat the ultrasound examination after one week; if the ratio increases, the diagnosis of hydrocephaly can be made without any doubt (Figs. 13, 14a). As the pregnancy proceeds and the ventricular dilatation increases, the ultrasound diagnosis of hydrocephaly becomes much easier: the lateral ventricles are extremely dilated and the $\mathrm{LVW} / \mathrm{HW}$ ratio is much higher than it normally is 


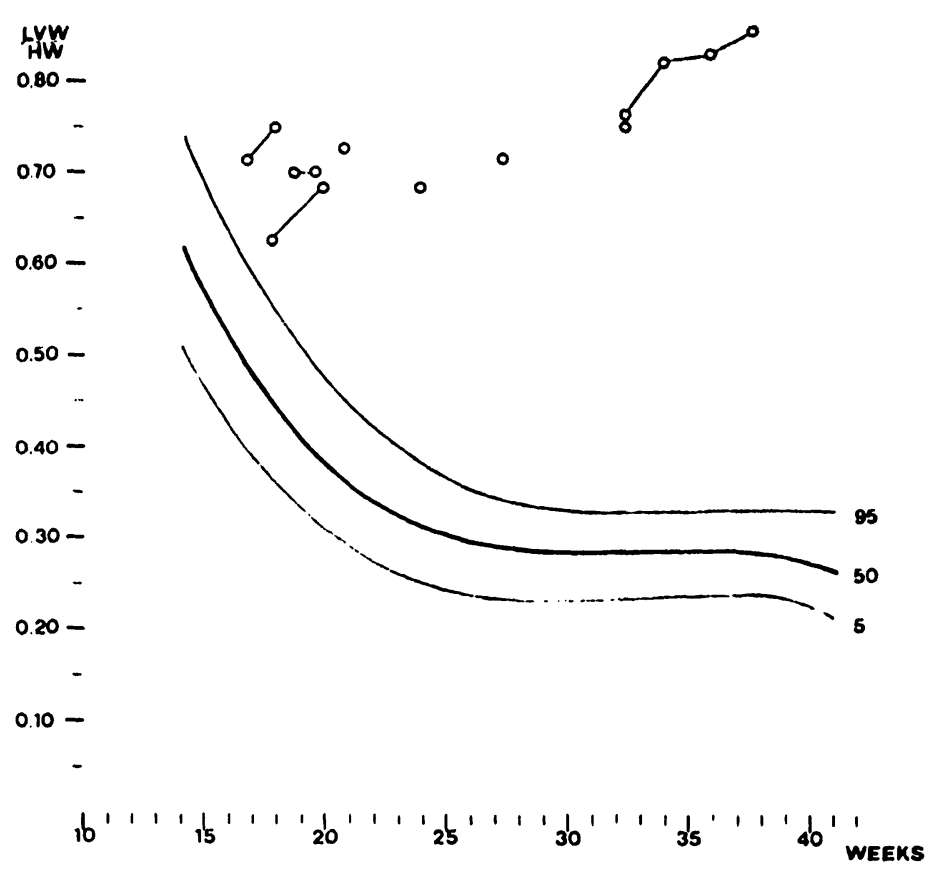

Fig. 13. LVW/HW ratios in 8 hydrocephalic fetuses.

(Figs. 13, 14b). Furthermore, real-time examination makes it possible to recognize the midline echo floating between the two dilated ventricles and the choroid plexi hanging in the cerebrospinal fluid inside the dilated ventricular cavities (Fig. 14b).

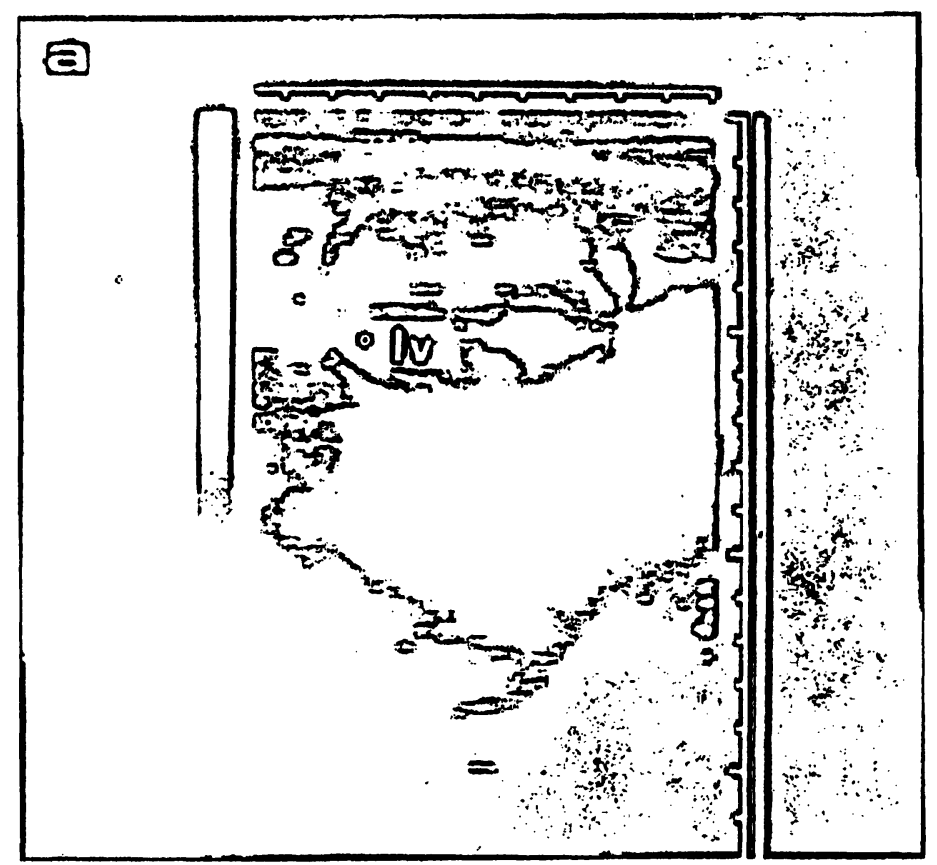

\section{Discussion}

There are certain difficulties in making an ultrasonic evaluation. For example, technical problems can sometimes give the illusion of the presence of asymmetric hydrocephaly when in fact it is the symmetrical variety that is present. Occasionally the image of the ventricle close to the transducer may be filled in with reverberation artifacts from the amniotic fluid-skull interface or as a result of poor gain settings. In these cases the ventricle near the transducer may not be fully detected, while the distal ventricle is well demonstrated and enlarged.

It appears that in early congenital hydrocephaly the occipital horns and atria dilate prior to enlargement of the body of the lateral ventricles [15]. Since the fetal occipital horns are ultrasonically recognizable less easily than the frontal ones, slight dilatation of the ventricular cavities can sometimes go unnoticed. There is no doubt that the improvement of the available instrumentation will allow a better ultrasonic visualization of the fetal ventricles and better measurements, thus assuring an earlier and more precise prenatal diagnosis of hydrocephaly.

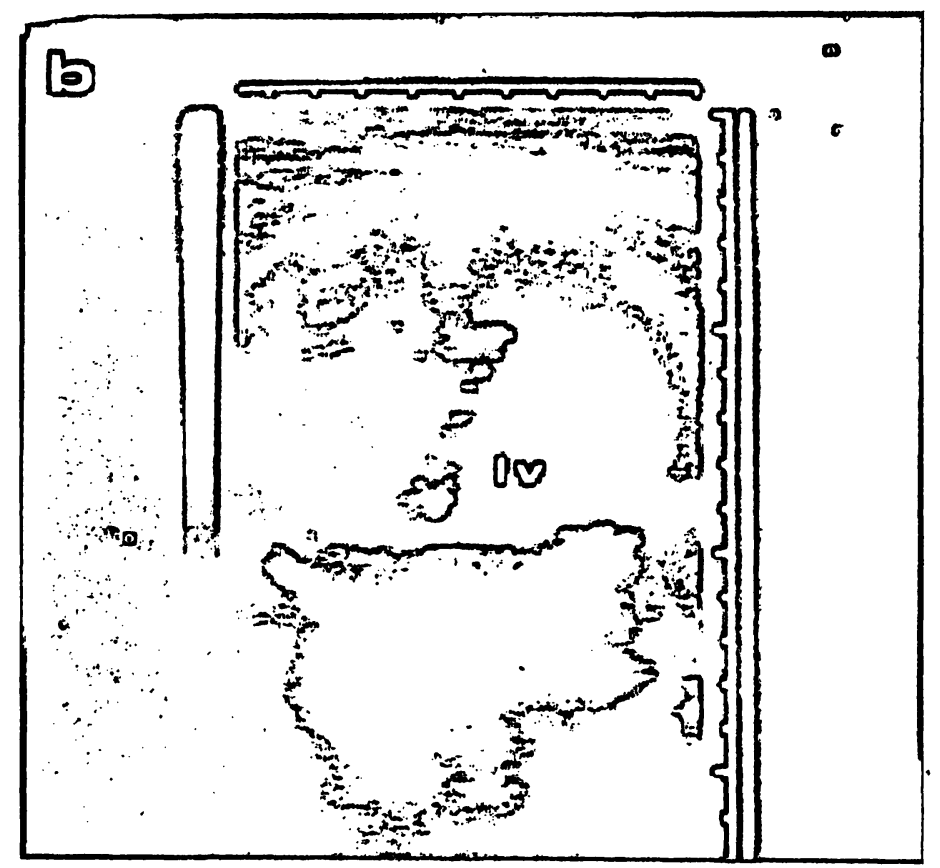

Fig. 14. Ultrasonic findings in two cases of hydrocephaly ( $a=20$ weeks; $b=34$ weeks). 


\section{Conclusion}

Real-time ultrasound equipment is now capable of delineating fetal intracranial anatomy throughout pregnancy from the 14th or 15 th week. Fetal hydrocephaly can be diagnosed even in the normal sized head by careful examination of the cerebral ventricles.

\section{Summary}

Significant recent advances in ultrasonic technology have now made possible detailed evaluation of normal and abnormal fetal intracranial anatomy.

Accurate knowledge of fetal intracranial anatomy is important for accurate and reproducible cephalometry as well as in antenatal diagnosis of dilated brain ventricles.

High resolution real-time ultrasonic investigation was performed in 280 normal obstetric patients from the 14 th to the 41 st weeks of pregnancy.

Eight patients with antenataly detected hydrocephalic fetuses were also included in the study. Measurements of the ratio between lateral ventricular width and cerebral hemispheric width (LVW/HW) showed value at 0.61 of the 14 th week to 0.29 at about the 27 th week. This value then remains unchanged until term. Accordingly the $\mathrm{LVW} / \mathrm{HW}$ ratio decreases as the fetus grows reflecting the developmental changes.

Keywords: Cerebral ventricles, hydrocephaly, ultrasonics.

\section{Zusammenfassung}

Ultraschalluntersuchung der fetalen Hirnventrikel

Bedeutende technologische Fortschritte ermöglichen heute eine genaue Ultraschalluntersuchung der normalen und pathologischen intracraniellen Anatomie beim Feten.

Wichtig für die exakte und reproduzierbare Cephalometrie wie auch für die antenatale Diagnose erweiterter Hirnventrikel ist die genaue Kenntnis der fetalen intracraniellen Anatomie. Bei 280 unkomplizierten geburtshilflichen Patientinnen wurden von der 14. bis zur 41 . Schwangerschaftswoche Ultraschalluntersuchungen mit einem Realtime-Scanner mit hoher Auflösung durchgeführt.

8 Patientinnen, bei deren Feten antenatal ein Hydrocephalus diagnostiziert wurde, wurden in die Studie miteinbezogen. Bei Bestimmung der Ratio zwischen Weite der Seitenventrikel und Dicke der Hemisphären (LVW/ HW) zeigten sich Werte von 0,61 in der 14 . Woche bis zu 0,29 etwa in der 27. Woche. Dieses Verhältnis bleibt Schlüsselwörter: Hirnventrikel, Hydrocephalus, Ultraschall.
Due to this simple measurement technique, it is possible to diagnose hydrocephaly much earlier than by means of the identification of an abnormal BPD growth or a discrepancy between head and abdomen circumferences. Although the earliest reported cases of prenatal ultrasound detection of hydrocephaly have been at 17-18 weeks, one must be very careful when making the diagnosis prior to 20 weeks because the lateral ventricles are usually disproportionally large at this time and the LVW/ $\mathrm{HW}$ ratio is, therefore, high. Morever, the normal range is rather wide at this age. For this reason it is useful to repeat the ultrasound examination after one week; if the ratio increases, the diagnosis of hydrocephaly can be made without any doubt. dann bis zum Termin unverändert; d.h., daß mit dem Wachstum des Feten die LVW/HW-Ratio abnimmt, was die Entwicklungsvorgänge widerspiegelt:

Dank dieser einfachen Untersuchungstechnik ist die Diagnose Hydrocephalus sehr viel früher möglich als über die Feststellung eines anormal großen BPD oder einer Diskrepanz zwischen Kopf- und Abdomenumfang.

Es wurden Fälle beschrieben, in denen durch Ultraschall ein Hydrocephalus in der 17./18. Woche diagnostiziert wurde. Bei einer Diagnose vor der 20. Woche ist jedoch zu bedenken, daß die Seitenventrikel zu diesem Zeitpunkt sehr weit sind und die LVW/HW-Ratio daher sehr groß ist. Darüber hinaus sind die Normalwerte in dieser Phase sehr breit gestreut. Es ist daher sinnvoll, die Ultraschalluntersuchung nach einer Woche zu wiederholen; nimmt die Ratio zu, ist die Diagnose Hydrocephalus ohne Zweifel erlaubt.

\section{Résumé}

Exploration échographique des ventricules cérébraux du fœtus

Les progrès récents significatifs de la technologie ultrasonore ont actuellement rendu possible l'évaluation détaillée de l'anatomie fœtale intra-cranienne normale et anormale.
La connaissance précise de l'anatomie intra-cranienne du fœtus est importante pour réaliser une céphalométrie précise et reproductible de même que pour diagnostiquer avant l'accouchement une hydrocéphalie.

On a réalisé une exploration ultrasonore à haute résolution en temps réel chez 280 femmes enceintes normales 
de la 14è à la 41è semaine de gestation. On a inclu dans l'étude 8 patientes chez lesquelles avait été détectée une hydrocéphalie fœtale. Les mesures des rapports entre la largeur des ventricules latéraux et la largeur des hémisphères cérébraux ( $\mathrm{LVW} / \mathrm{HW}$ ) ont donné des valeurs allant de 0,61 à la 14 è semaine à 0,29 à environ 27 semaines. Cette dernière valeur ne se modifie pas jusqu'au terme. Néanmoins, le rapport $\mathrm{LVW} / \mathrm{HW}$ diminue avec la croissance fœtale; il reflète les modifications en rapport avec le développement. Grâce à cette simple technique de mesure, il est possible de diagnostiquer une hydrocéphalie plus précocément qu'au moyen de la détermination d'une croissance anormale du BIP ou d'une divergence entre les circonférences céphaliques et abdominales.

Mots-clés: Hydrocéphalie, ultrasons, ventricules cérébraux.
Bien que les cas les plus précocément rapportés de diagnostic prénatal échographique d'hydrocéphalie l'aient été à 17-18 semaines, il faut être très prudent lorsque l'on porte ce diagnostic avant la 20è semaine car les ventricules latéraux sont généralement volumineux de façon disproportionnée à cette époque, avec un rapport LVW/HW élevé. De plus, les valeurs normales sont assez étendues à cet âge. C'est pour cette raison qu'il est utile de refaire un examen échographique au bout d'une semaine; si le rapport s'élève, le diagnostic d'hydrocéphalie peut être porté sans doute.

\section{Bibliography}

[1] CAMPBElL, S., A. Thomas: Ultrasound measurement of the fetal head to abdomen circumference ratio in the assessment of growth retardation. Br. J. Obstet. Gynaecol. 84 (1977) 165

[2] CAMPBELL, S.: Diagnosis of fetal abnormalities by ultrasound. In: MILUNSKY, A. (Ed.): Genetic disorders and the fetus. Plenum Press Ed., New York, London 1979, p. 431

[3] CRADE, M., J. PATEL, D. MCQUOWN: Sonographic imaging of the glycogen stage of the fetal choroid plexus. AJNR 2 (1981) 345

[4] DUME, M. G., M. L. JOHNSON: The ultrasonic demonstration of fetal abnormalities in utero. J. Reprod. Med. 23 (1979) 195

[6] DENKHAUS, H., F. WINSBERG: Ultrasonic measurement of the fetal ventricular system. Radiology 131 (1979) 781

[7] FREEMAN, R. K., D. S. MCQUOWN, L. J. SCERIST: The diagnosis of fetal hydrocephalus before viability. Obstet. Gynecol. 49 (1977) 1

[9] HAMILTON, W. J., J. D. BOYD, H. W. MOSSMAN: Human embriology (Prenatal development of form and function). Heffer Ed., Cambridge 1964

[10] HADLOCK, F. P., R. L. DETER, S. K. PARK: Realtime sonography: Ventricular and vascular anatomy of the fetal brain in utero. AJR 136 (1981) 133

[11] JEANTY, P., M. DRAMIX-WILMET, D. DELBEKE et al.: Ultrasonic evaluation of fetal ventricular growth. Neuroradiology 21 (1981) 127

[12] JOHNSON, M. L., M. G. DUNNE, I. A. MACK et al.: Evaluation of fetal intracranial anatomy by static and real-time ultrasound. JCU 8 (1980) 311

[13] KAFFERS, J. A.: Structure and functional changes in the telencephalic choroid plexus during human ontogenesis. In: CIBA Foundation Symposium Cerebrospinal fluid. 1958, pp. 3; 31

[14] KOSSOFF, G.: Monitoraggio con gli ultrasuoni dello sviluppo del cervello fetale. In: DESTRO, F. (Ed.): Ultrasuoni in Ostetricia. Proceedings of the international course on ultrasound in obstetrics, Gorizia April 15-17, 1981. Monduzzi Ed., Bologna 1981, p. 127

[15] KURJAK, A.: Grauwertdarstellung in der Früh- und Spätdiagnose von Feten mit Hydrozephalus. Ultraschall 1 (1980) 270

[16] KURJAK, A., V. LATIN, V. D'ADDARIO: Abnormalities of the fetus, placenta and umbilical cord. In: KURJAK, A. (Ed.): Progress in Medical Ultrasound, Vol. 3. Excerpta Medica, AmsterdamOxford-Princeton 1982, p. 87

[17] KURJAK, A., V. D'ADDARIO: Gli ultrasuoni in Ostetricia e Ginecologia. Piccin Ed., Padova 1982, p. 72

[18] LITTLE, D. J., S. CAMPBELL: The Diagnosis of Spina Bifida and Intracranial Anomalies. In: SANDERS, R. C., A. E. JAMES (Eds.): The principle and practice of ultrasonography in obstetrics and gynecology. Appleton-Century-Crofts, New York 1980 , Chap. 15 , p. 179

Received February 20, 1984. Accepted March 19, 1984.

Vincenzo D'Addario, M.D. Università di Bari Clinica Ostetrica e Gin. I Policlinico 70124 Bari/Italy 


\section{Culture Techniques}

\section{Applicability for Studies on Prenatal Differentiation} and Toxicity

\section{Fifth Symposium on Prenatal Development}

\section{May, 1981, Berlin}

Edited by $D$. Neubert and H.J. Merker with the assistence of J. Klein-Friedrich and $R$. Kreft.

1982. $15,5 \times 23 \mathrm{~cm} .621$ pages. With numerous illustrations and tables.

Bound DM 98,- ISBN 3110087545

This book deals with the applicability of the in vitro technique, a method which recently is gaining in attention. The topics include:

I. Studies on Whole-Embryo Culture

II. Studies on Organ Cultures

III. Studies on Pre-Implantation Embryos

IV. Studies on Cell and Tissue Cultures

V. Studies on Non-Mammalian Tissues

VI. Culture Techniques for "Screening" on Teratogenicity

VII. Some Methods used for Culturing Embryonic Tissues

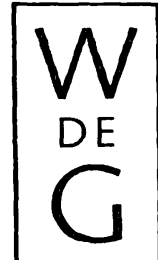

